\title{
pH-Dependent isotope exchange and hydrogenation catalysed by water- soluble NiRu complexes as functional models for [NiFe]hydrogenases $\dagger$
}

\author{
Bunsho Kure $^{a}$, Takahiro Matsumoto ${ }^{a}$, Koji Ichikawa ${ }^{a}$, Shunichi Fukuzumi ${ }^{b}$, Yoshiki Higuchi ${ }^{c}$, Tatsuhiko \\ Yagi $^{d}$ and Seiji Ogo ${ }^{a}$
}

\author{
${ }_{5}$ Received 6th May 2008, Accepted 16th July 2008 \\ First published as an Advance Article on the web $30^{\text {th }}$ July 2008 \\ DOI: 10.1039/b807555g
}

The $\mathrm{pH}$-dependent hydrogen isotope exchange reaction between gaseous isotopes and medium isotopes and hydrogenation of the carbonyl compounds have been investigated with water-soluble bis $(\mu$-thiolate $)(\mu$-hydride $) \mathrm{NiRu}$ complexes, Ni ${ }^{\mathrm{II}}(\mu-\mathrm{SR})_{2}\left(\mu\right.$-H)Ru ${ }^{\mathrm{II}}$

$10\left\{(\mu \text {-SR })_{2}=N, N^{\prime}\right.$-dimethyl- $N, N$ '-bis(2-mercaptoethyl)-1,3-propanediamine $\}$, as functional models for [NiFe]hydrogenases. In acidic media (at $\mathrm{pH} 4-6$ ), the $\mu-\mathrm{H}$ ligand of the $\mathrm{Ni}^{\mathrm{II}}(\mu-\mathrm{SR})_{2}(\mu-\mathrm{H}) \mathrm{Ru}^{\mathrm{II}}$ complexes has $\mathrm{H}^{+}$properties, and the complexes catalyse the hydrogen isotope exchange reaction between gaseous isotopes and medium isotopes. A mechanism of the hydrogen isotope exchange reaction between gaseous isotopes and medium isotopes through a low-valent $\mathrm{Ni}^{\mathrm{I}}(\mu-\mathrm{SR})_{2} \mathrm{Ru}^{\mathrm{I}}$ complex is proposed. In contrast, in neutral-basic media (at $\mathrm{pH} 7-10)$, the $\mu-\mathrm{H}$ ligand of the $\mathrm{Ni}^{\mathrm{II}}(\mu-\mathrm{SR})_{2}(\mu-\mathrm{H}) \mathrm{Ru}^{\mathrm{II}}$ complexes acts as $\mathrm{H}^{-}$, and the 15 complexes catalyse the hydrogenation of carbonyl compounds.

\section{Introduction}

Hydrogenases ( $\mathrm{H}_{2}$ ases $)$ are enzymes that catalyse the reversible interconversion of $\mathrm{H}_{2}$ into two protons and two 20 electrons under ambient conditions. ${ }^{1,2}$ The enzymes also catalyse hydride transfer and electronic reduction of the electron carriers (e.g., $\mathrm{NAD}^{+}$and cytochrome $\mathrm{c}_{3}$ ) with $\mathrm{H}_{2}{ }^{3}{ }^{3-10}$

$\mathrm{H}_{2}$ ases are classified into two major families on the basis of the metal content of their respective dinuclear active sites, i.e., $25[\mathrm{NiFe}] \mathrm{H}_{2}$ ases $^{11-13}$ and $[\mathrm{FeFe}] \mathrm{H}_{2}$ ases. $^{14,15}$ X-Ray analysis, spectroscopic techniques and theoretical methods on the structures of the $\mathrm{H}_{2}$ ases have shown that the active sites of both types of $\mathrm{H}_{2}$ ases have characteristic bimetallic units with bis( $\mu$-thiolato) ligands, $\mathrm{M}(\mu \text {-SR' })_{2} \mathrm{M}\left\{\mathrm{M}=\mathrm{Ni}\right.$ or $\mathrm{Fe},(\mu \text {-SR })_{2}$ $30=$ two bridging cysteine residues, 1,3-propanedithiolato or di(thiomethyl)amine , and unidentified ligands (depicted as $\mathrm{X}$ in Fig. 1). ${ }^{11-16}$ The unidentified ligands are proposed to be oxygen ligands such as $\mathrm{H}_{2} \mathrm{O}, \mathrm{OH}^{-}$or $\mathrm{O}_{2}^{-}$in the resting state, and might be a hydride $\left(\mathrm{H}^{-}\right)$ligand in the active state. ${ }^{11,14-16}$

${ }^{a}$ Center for Future Chemistry, Kyushu University, 744 Moto-oka, Nishi-ku, Fukuoka 819-0395, Japan.E-mail: ogo-tcm@mbox.nc.kyushu-u.ac.jp; 40 Fax: +81 92802 3308; Tel: +8192 8023295

${ }^{b}$ Department of Material and Life Science, Division of Advanced Science and Biotechnology, Graduate School of Engineering, Osaka University, Solution Oriented Research for Science and Technology, Japan Science and Technology Agency (JST), Suita, Osaka 565-0871, Japan

${ }_{45}{ }^{c}$ Department of Life Science, Graduate School of Life Science, University of Hyogo, Koto, Kamigori, Hyogo 678-1297, Japan

${ }^{d}$ Shizuoka University, 836 Oya, Shizuoka, 422-8529, Japan † Electronic supplementary information (ESI) available: Electrospray ionisation mass spectra of 2 (Fig. S1), IR spectra of 2 (Fig. S2), ${ }^{1} \mathrm{HNMR}$

50 spectrum of 4 in $\mathrm{H}_{2} \mathrm{O}$ (Fig. S3), pH-dependent profile of TOFs for the hydrogenation of glyoxylic acid (Fig. S4) and XPS of 1, 2 and 3 (Fig. S5). See DOI: $10.1039 / \mathrm{b} 807555 \mathrm{~g}$ (a)
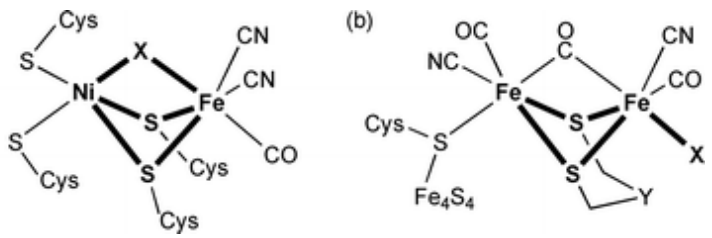

Fig. 1 Active site structures of resting forms of $[\mathrm{NiFe}] \mathrm{H}_{2}$ ases (a) and [FeFe] $\mathrm{H}_{2}$ ases (b) $\left(\mathrm{X}=\mathrm{H}_{2} \mathrm{O}, \mathrm{OH}^{-}\right.$or $\mathrm{O}^{2-}, \mathrm{Y}=\mathrm{CH}_{2}$ or $\left.\mathrm{NH}\right)$.

Important parts of our understanding of the $\mathrm{H}_{2}$-activation mechanism come from studies on protein film voltammetry ${ }^{17}$ 60 and the hydrogen isotope exchange reaction between gaseous isotopes $\left(\mathrm{H}_{2}\right.$, $\mathrm{HD}$ and $\left.\mathrm{D}_{2}\right)$ and medium isotopes $\left(\mathrm{H}^{+} \text {and } \mathrm{D}^{+}\right)^{18-}$ ${ }^{30}$ catalysed by $\mathrm{H}_{2}$ ases (eqn (1)), i.e., $\mathrm{H}_{2}$ bound to the enzyme (E) is split heterolytically to form $\mathrm{H}^{+}$and an enzyme hydride $\left(\mathrm{EH}^{-}\right.$) (eqn (2)). ${ }^{18-21}$ The backward reaction in eqn (2) 65 regenerates $\mathrm{H}_{2}$. In $\mathrm{D}_{2} \mathrm{O}, \mathrm{EH}^{-}$should react with $\mathrm{D}^{+}$to provide $\mathrm{E}$ with evolution of $\mathrm{HD}$ (eqn (3)). In such a case, $\mathrm{H}_{2}$ must be initially converted to $\mathrm{HD}$ as a single exchange product and then $\mathrm{D}_{2}$ as a double exchange product in $\mathrm{D}_{2} \mathrm{O}$, i.e., the generation of $\mathrm{HD}$ and $\mathrm{D}_{2}$ must be sequential. ${ }^{18}$ However, all 70 experiments of hydrogen isotope exchange reaction between gaseous isotopes and medium isotopes with $\mathrm{H}_{2}$ ases performed till now have shown that the single exchange product (HD) and the double exchange products $\left(\mathrm{D}_{2}\right.$ or $\left.\mathrm{H}_{2}\right)$ were formed simultaneously. ${ }^{18-30}$ Thus, the detail of the mechanism of the 75 hydrogen isotope exchange reaction between gaseous isotopes and medium isotopes has so far been the subject of controversy.

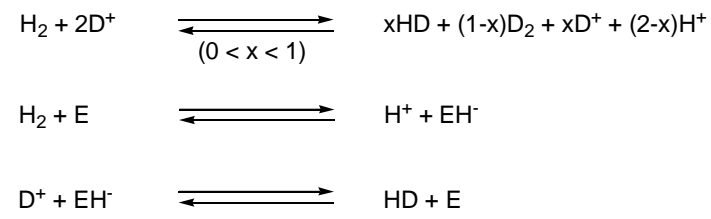


Table 1 Hydrogen isotope exchange reaction between gaseous isotopes $\left(\mathrm{H}_{2}, \mathrm{HD}\right.$ and $\left.\mathrm{D}_{2}\right)$ and medium isotopes $\left(\mathrm{H}^{+}\right.$and $\left.\mathrm{D}^{+}\right)$and hydrogenation of substrates catalysed by $\mathrm{M}(\mu-\mathrm{Z})_{2} \mathrm{M}(\mathrm{M}=$ metal ions, $\mathrm{Z}$ = thiolato, sulfido or hydrosulfido ligands) complexes

\begin{tabular}{|c|c|c|c|c|c|}
\hline \multirow[b]{2}{*}{ Entry } & \multirow[b]{2}{*}{ Catalyst } & \multicolumn{2}{|c|}{ Isotope exchange } & \multicolumn{2}{|l|}{ Hydrogenation } \\
\hline & & System & Time-dependent generation of isotopes & Substrate/product & Solvent \\
\hline $1^{a}$ & & $\begin{array}{l}\mathrm{H}_{2} / \mathrm{D}^{+} \\
\mathrm{D}_{2} / \mathrm{H}^{+}\end{array}$ & $\mathrm{ND}^{e}$ & Ethylene/ethane & Dichloromethane \\
\hline $2^{b}$ & & $\mathrm{H}_{2} / \mathrm{D}^{+}$ & $\mathrm{ND}^{e}$ & Sulfur/hydrogen sulfide $f$ & Chloroform- $d_{1}$ \\
\hline $3^{c}$ & & - & - & Cyclohexene/cyclohexane & Toluene \\
\hline $4^{d}$ & & - & - & $\begin{array}{l}\text { 1-Octyne/octane, 1-octene } \\
\text { and 2-octene }\end{array}$ & Acetone \\
\hline 5 & This work & $\begin{array}{l}\mathrm{H}_{2} / \mathrm{D}^{+} \\
\mathrm{D}_{2} / \mathrm{H}^{+}\end{array}$ & Simultaneous & $\begin{array}{l}\text { Benzaldehyde/benzyl } \\
\text { alcohol }\end{array}$ & Water \\
\hline
\end{tabular}

${ }^{a}$ Ref. 32-35. ${ }^{b}$ Ref. 36. ${ }^{c}$ Ref. 39. ${ }^{d}$ Ref. 40. ${ }^{e}$ ND: not determined. ${ }^{f}$ Hydrogenation of $\beta$-bromostyrene and azobenzene was also reported by similar complexes (ref. 37 and 38 ).

5 There are a few studies of the hydrogen isotope exchange reaction between gaseous isotopes and medium isotopes and hydrogenation of unsaturated compounds catalysed by the $\mathrm{M}(\mu-\mathrm{Z})_{2} \mathrm{M} \quad(\mathrm{M}=$ metal ions, $\mathrm{Z}=$ thiolato, sulfido or hydrosulfido ligands) complexes (Table 1). ${ }^{31-40}$ However,

10 time-dependent hydrogen isotope exchange reaction between gaseous isotopes and medium isotopes has never been carried out with the $\mathrm{M}(\mu-\mathrm{Z})_{2} \mathrm{M}$ complexes (indicated as ND in Table 1). ${ }^{41-50}$ All hydrogenation with the $\mathrm{M}(\mu-\mathrm{Z})_{2} \mathrm{M}$ complexes proceeds in organic solvents but not in water in which the ${ }_{15} \mathrm{H}_{2}$ ases operate.

Frontier works on model studies for $[\mathrm{NiFe}] \mathrm{H}_{2}$ ases have been carried out by Rauchfuss and co-workers, Artero and Fontecave and co-workers and DuBois and co-workers. ${ }^{51,52}$

We recently reported ${ }^{\underline{53}}$ the synthesis and structures of 20 water-soluble $\quad\left[\mathrm{Ni}^{\mathrm{II}}(\mu-\mathrm{SR})_{2} \mathrm{Ru}^{\mathrm{II}}\left(\mathrm{OH}_{2}\right)\left(\eta^{6}-\mathrm{C}_{6} \mathrm{Me}_{6}\right)\right](\mathrm{OTf})_{2}$ $\left\{[1](\mathrm{OTf})_{2}, \quad(\mu-\mathrm{SR})_{2}=N, N^{\prime}\right.$-dimethyl- $N, N^{\prime}$-bis $(2-$ mercaptoethyl)-1,3-propanediamine, OTf $\left.=\mathrm{CF}_{3} \mathrm{SO}_{3}\right\}$ and $\left[\mathrm{Ni}^{\mathrm{II}}\left(\mathrm{OH}_{2}\right)(\mu-\mathrm{SR})_{2}(\mu-\mathrm{H}) \mathrm{Ru}^{\mathrm{II}}\left(\eta^{6}-\mathrm{C}_{6} \mathrm{Me}_{6}\right)\right]\left(\mathrm{NO}_{3}\right) \quad\left\{[2]\left(\mathrm{NO}_{3}\right)\right\}$ as functional models for the resting form (E) and the active form ${ }_{25}\left(\mathrm{EH}^{-}\right)$of $[\mathrm{NiFe}] \mathrm{H}_{2}$ ases, respectively (Fig. 2). ${ }^{54}$ The structuresof $\mathbf{1}$ and $\mathbf{2}$ were determined by X-ray and neutron diffraction analyses.

We report herein the $\mathrm{pH}$-dependent hydrogen isotope exchange reaction between gaseous isotopes and medium 30 isotopes at $\mathrm{pH}$ 4-6 catalysed by $\mathbf{2}$ via a low-valent intermediate $\quad\left[\mathrm{Ni}^{\mathrm{I}}(\mu-\mathrm{SR})_{2} \mathrm{Ru}^{\mathrm{I}}\left(\eta^{6}-\mathrm{C}_{6} \mathrm{Me}_{6}\right)\right] \quad$ (3), and hydrogenation of the carbonyl compounds at $\mathrm{pH}$ 7-10 catalysed by $\left[\mathrm{Ni}^{\mathrm{II}}(\mathrm{OH})(\mu-\mathrm{SR})_{2}(\mu-\mathrm{H}) \mathrm{Ru}^{\mathrm{II}}\left(\eta^{6}-\mathrm{C}_{6} \mathrm{Me}_{6}\right)\right] \quad$ (4), which is a deprotonated species of 2 whose $\mathrm{p} K_{\mathrm{a}}$ value is 6.5 35 (Fig. 3).
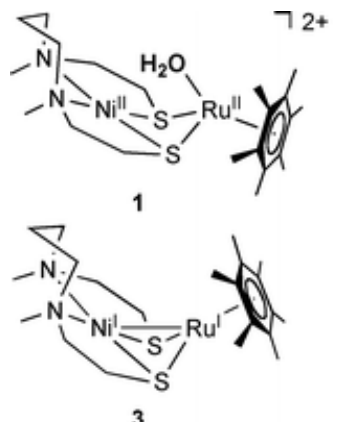

(a low-valent complex)

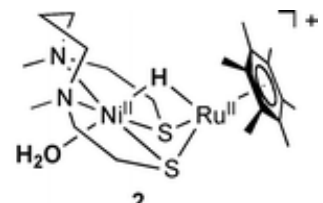

2

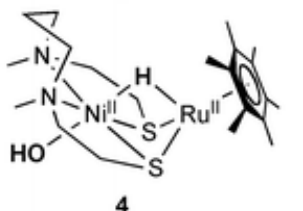

(deprotonated form of 2)
Fig. 2 Water-soluble $\mathrm{Ni}(\mu-\mathrm{SR})_{2} \mathrm{Ru}\left\{(\mu-\mathrm{SR})_{2}=N, N^{\prime}\right.$ Fig. 2 Watersoluble $\quad \mathrm{Ni}(\mu-\mathrm{SR})_{2} \mathrm{Ru} \quad\left\{(\mu-\mathrm{SR})_{2}=N, N^{\prime}\right.$-dimethyl- $N, N^{\prime}$-bis(2mercaptoethyl)-1,3-propanediamine\} complexes 1-4.

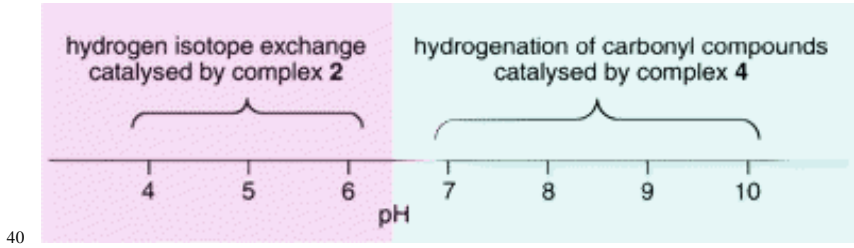

Fig. $3 \mathrm{pH}$-Dependent hydrogen isotope exchange reaction between gaseous isotopes and medium isotopes and hydrogenation of the carbonyl compounds catalysed by the $\mathrm{Ni}(\mu-\mathrm{H}) \mathrm{Ru}$ complexes. 


\section{Experimental}

\section{Materials and methods}

$\left[\mathrm{Ni}^{\mathrm{II}}(\mu-\mathrm{SR})_{2} \mathrm{Ru}^{\mathrm{II}}\left(\mathrm{OH}_{2}\right)\left(\eta^{6}-\mathrm{C}_{6} \mathrm{Me}_{6}\right)\right](\mathrm{OTf})_{2}\left\{[\mathbf{1}](\mathrm{OTf})_{2},(\mu-\mathrm{SR})_{2}\right.$ $=\quad N, N^{\prime}$-dimethyl- $N, N^{\prime}$-bis(2-mercaptoethyl)-1,35 propanediamine, OTf $=\mathrm{CF}_{3} \mathrm{SO}_{3}$ \} was prepared by the method described in the literature. ${ }^{53}\left[\mathrm{Ni}^{\mathrm{II}}\left(\mathrm{OH}_{2}\right)(\mu-\mathrm{SR})_{2}(\mu-\mathrm{H}) \mathrm{Ru}^{\mathrm{II}}\left(\eta^{6}-\right.\right.$ $\left.\left.\mathrm{C}_{6} \mathrm{Me}_{6}\right)\right]\left(\mathrm{NO}_{3}\right)\left\{[2]\left(\mathrm{NO}_{3}\right)\right\}$ was synthesised from the reaction of 1 with $\mathrm{H}_{2}$ (0.1 MPa) in the range of $\mathrm{pH} 4-7$ at $25{ }^{\circ} \mathrm{C} .{ }^{53}$ The manipulations in the acidic media were carried out with 10 plastic- and glass-ware (without metals). Distilled water, 0.1 $\mathrm{M} \mathrm{NaOH} / \mathrm{H}_{2} \mathrm{O}$ and $0.1 \mathrm{M} \mathrm{HNO}_{3} / \mathrm{H}_{2} \mathrm{O}$ were purchased from Wako Pure Chemical Industries, Ltd., $65 \% \mathrm{DNO}_{3} / \mathrm{D}_{2} \mathrm{O}(99 \%$ D) was purchased from Isotec Inc., $\mathrm{K}_{2} \mathrm{DPO}_{4}(99 \% \mathrm{D})$ was purchased from CDN Isotopes, $\mathrm{CH}_{3} \mathrm{COOD}$ (99\% D) was 15 purchased from Aldrich Co., and $\mathrm{D}_{2} \mathrm{O}(99.9 \% \mathrm{D}), 40 \%$ $\mathrm{NaOD} / \mathrm{D}_{2} \mathrm{O}(99 \% \mathrm{D})$ and $\mathrm{KD}_{2} \mathrm{PO}_{4}(98 \% \mathrm{D})$ were purchased from Cambridge Isotope Laboratories, Inc.; these reagents were used as received. $\mathrm{H}_{2}$ gas (99.9999\%) was purchased from Taiyo Toyo Sanso Co., Ltd., $\mathrm{D}_{2}$ gas (99.5\%) was 20 purchased from Sumitomo Seika Chemicals Co., Ltd., and HD gas (HD 97\%, $\mathrm{H}_{2} 1.8 \%, \mathrm{D}_{2} 1.2 \%$ ) was purchased from Isotec Inc.; these were used without further purification.

Matrix-assisted laser desorption/ionisation time-of-flight mass spectrometry (MALDI-TOF-MS) was recorded on

25 ultraflex TOF/TOF (Bruker Daltonics), where dithranol was used as a matrix. Electrospray ionisation mass spectrometry (ESI-MS) data were obtained by an API 365 triple-quadrupole mass spectrometer (PE-Sciex) in the positive detection mode, equipped with an ion spray interface. The sprayer was held at 30 a potential of $+5.0 \mathrm{kV}$, and compressed $\mathrm{N}_{2}$ was employed to assist liquid nebulisation. ${ }^{1} \mathrm{H}$ NMR spectra were recorded on a JEOL JNM-AL300 spectrometer at $23{ }^{\circ} \mathrm{C}$. $\mathrm{H}_{2}$, HD and $\mathrm{D}_{2}$ gases were determined using Shimadzu GC-14B and GC-8A (He carrier) with a $\mathrm{MnCl}_{2}$-alumina column (model: Shinwa ${ }_{35}$ OGO-SP) at $-196{ }^{\circ} \mathrm{C}$ (liquid $\mathrm{N}_{2}$ ) and equipped with a thermal conductivity detector. IR spectra were recorded on a Thermo Nicolet NEXUS 8700 FT-IR instrument from 650 to $4000 \mathrm{~cm}^{-}$ ${ }^{1}$ using $2 \mathrm{~cm}^{-1}$ standard resolution at ambient temperature. XRay photoelectron spectra (XPS) were measured on a VG ${ }_{40}$ Scientific ESCALAB MK II electron spectrometer by use of $\mathrm{Mg}-\mathrm{K} \alpha$ radiation, and the binding energies were corrected by assuming a $\mathrm{C} 1 \mathrm{~s}$ binding energy of the carbon atoms of the ligand in the specimens as $284.5 \mathrm{eV}{ }^{55} \mathrm{~A}$ magnetic stirrer (model: Nissin SW-R700) was used.

45 The $\mathrm{pH}$ of the solution was adjusted by using $0.1 \mathrm{M}$ $\mathrm{HNO}_{3} / \mathrm{H}_{2} \mathrm{O}(\mathrm{pH} 1-3), 25 \mathrm{mM} \mathrm{CH} \mathrm{COOH}_{3} \mathrm{CH}_{3} \mathrm{COONa}(\mathrm{pH} 4-$ 6), $25 \mathrm{mM} \mathrm{Na} \mathrm{HPO}_{4} / \mathrm{KH}_{2} \mathrm{PO}_{4}(\mathrm{pH} 7-8)$ and $0.1 \mathrm{M} \mathrm{NaOH} / \mathrm{H}_{2} \mathrm{O}$ (pH 9-10) solutions. In a pH range of 1.0-11.0, the pH of the solution was determined by a $\mathrm{pH}$ meter (model: TOA HM-5A) 50 equipped with a glass electrode (model TOA GS-5015C). pD Values were corrected by adding 0.4 to the observed values $(\mathrm{pD}=\mathrm{pH}$ meter reading +0.4$) .{ }^{56,57}$ In the biphasic media, the $\mathrm{pH}$ value of the aqueous phase is adopted.

\section{${ }_{55}\left[\mathrm{Ni}^{\mathrm{II}}\left(\mathrm{OH}_{2}\right)(\mu-\mathrm{SR})_{2}(\mu-\mathrm{D}) \mathrm{Ru}^{\mathrm{II}}\left(\eta^{6}-\mathrm{C}_{6} \mathrm{Me}_{6}\right)\right]\left(\mathrm{NO}_{3}\right)$ 2] $\left.\left(\mathrm{NO}_{3}\right)\right\}$}

The aqua complex [1] $\left(\mathrm{NO}_{3}\right)_{2}(125 \mathrm{mg}, 0.2 \mathrm{mmol})$ was added to a $\mathrm{D}_{2} \mathrm{O}$ solution $(5 \mathrm{~mL})$ of $\mathrm{K}_{2} \mathrm{DPO}_{4} / \mathrm{KD}_{2} \mathrm{PO}_{4}(25 \mathrm{mM})$ at $\mathrm{pD}$ 5. $\mathrm{D}_{2}(0.1 \mathrm{MPa})$ was bubbled through the solution at $23{ }^{\circ} \mathrm{C}$ to ${ }_{60}$ gradually precipitate dark-red crystals of [D-labeled 2] $\left(\mathrm{NO}_{3}\right)$. After $3 \mathrm{~h}$ of $\mathrm{D}_{2}$ bubbling, the crystals were isolated by filtration. Further solid [D-labeled 2] $\left(\mathrm{NO}_{3}\right)$ was obtained by evaporating the filtrate to $\mathrm{ca} .1 \mathrm{~mL}$ below $30{ }^{\circ} \mathrm{C}$ \{yield: $80 \%$ based on $\left.[1]\left(\mathrm{NO}_{3}\right)_{2}\right\}$. ESI-MS analysis of the filtrate has 65 shown a prominent signal at $\mathrm{m} / \mathrm{z} 544.2$ \{[D-labeled $\left.2-\mathrm{H}_{2} \mathrm{O}\right]^{+}$; relative intensity $(I)=100 \%$ in the range of $\mathrm{m} / \mathrm{z} 100-2000\}$. FT-IR ( $\mathrm{cm}^{-1}$, as a $\mathrm{KBr}$ disk): 1248 (Ni-D-Ru).

\section{$\left[\mathrm{Ni}^{\mathrm{I}}(\mu-\mathrm{SR})_{2} \mathbf{R u}^{\mathrm{I}}\left(\eta^{6}-\mathrm{C}_{6} \mathrm{Me}_{6}\right)\right](3)$}

70 Complex [2] $\left(\mathrm{NO}_{3}\right)(15.0 \mathrm{mg}, 24.1 \mu \mathrm{mol})$ was dissolved in $\mathrm{H}_{2} \mathrm{O}(2.0 \mathrm{~mL})$ at $\mathrm{pH} 4$ (25 mM sodium acetate buffer), and $\mathrm{H}_{2}$ gas was bubbled through the solution at $23^{\circ} \mathrm{C}$. After $1 \mathrm{~h}$, the solution was evaporated to give a dark red crude oil, which was extracted with chloroform $(1 \times 3 \mathrm{~mL})$ and the resulting 75 solution was filtered and evaporated under reduced pressure to give a dark red powder of 3 yyield: $81 \%$ based on [2] $\left(\mathrm{NO}_{3}\right)$ \}. ${ }^{1} \mathrm{H}$ NMR (in $\mathrm{CDCl}_{3}$, reference to TMS, $23{ }^{\circ} \mathrm{C}$ ): $\delta 2.12$ (s, $18 \mathrm{H}$, $\left.\eta^{6}-\mathrm{C}_{6} \mathrm{Me}_{6}\right), 1.80-3.08\left\{\mathrm{~m}, 20 \mathrm{H},(\mu-\mathrm{SR})_{2}\right\}$. Anal. calc. for 3. $\mathrm{CH}_{3} \mathrm{COONa}: \mathrm{C}_{23} \mathrm{H}_{41} \mathrm{~N}_{2} \mathrm{NaNiO}_{2} \mathrm{RuS}_{2}$ : C, 44.24; H, 6.62; N, ${ }_{80} 4.49 \%$. Found: C, 43.92; H, 6.99; N, 4.20\%. It was confirmed by ${ }^{1} \mathrm{H}$ NMR that the sample for the elemental analysis included one equivalent of sodium acetate, which could be derived from the buffer solution of $\mathrm{CH}_{3} \mathrm{COOH} / \mathrm{CH}_{3} \mathrm{COONa}$. MALDI-TOF-MS: $\mathrm{m} / \mathrm{z} 542.1\left([3]^{\circ+} ; I=100 \%\right.$ in the range of ${ }_{85} \mathrm{~m} / \mathrm{z}$ 200-1000). FT-IR ( $\mathrm{cm}^{-1}$, as a $\mathrm{KBr}$ disk): 2957 (aliphatic C-H), 2924 (aliphatic C-H), 2854 (aliphatic C-H), 1720, 1576 (aromatic $\mathrm{C}=\mathrm{C}$ ), 1457 (aromatic $\mathrm{C}=\mathrm{C}$ ), 1263, 1197, 1178, 1150, 1111, 1072, 1017, 969, 872, 862, 833, 776, 749. XPS: $852.7 \mathrm{eV}$ (Ni 2 $\mathrm{p}_{3 / 2}$ region), $279.4 \mathrm{eV}$ ( $\mathrm{Ru} \mathrm{3d_{5/2 }}$ region).

\section{$\left[\mathrm{Ni}^{\mathrm{II}}(\mathrm{OH})(\mu-\mathrm{SR})_{2}(\mu-\mathrm{H}) \mathrm{Ru}^{\mathrm{II}}\left(\eta^{6}-\mathrm{C}_{6} \mathrm{Me}_{6}\right)\right]$ (4)}

Complex 4 can be prepared from complex 1 (method A) or complex 2 (method B) as starting materials as follows.

95 Method A. The aqua complex [1] $\left(\mathrm{NO}_{3}\right)_{2}$ (125 mg, 0.20 mmol) was added to an $\mathrm{H}_{2} \mathrm{O}$ solution (5 mL, pH 9) of $\mathrm{Na}_{3} \mathrm{PO}_{4} \cdot 12 \mathrm{H}_{2} \mathrm{O}$ (95mg, $0.25 \mathrm{mmol}$ ). $\mathrm{H}_{2}$ was bubbled through the solution at $25{ }^{\circ} \mathrm{C}$ to gradually precipitate dark-red solids of 4. After $3 \mathrm{~h}$, the solids were collected by filtration, and dried 100 in vacuo. Further solid 4 was obtained by concentrating the filtrate to ca.1mL below30 ${ }^{\circ} \mathrm{C}$ total yield: $72 \%$ based on $\left.[1]\left(\mathrm{NO}_{3}\right)_{2}\right\}$.

Method B. Complex [2] $\left(\mathrm{NO}_{3}\right)(10.0 \mathrm{mg}, 16.0 \mu \mathrm{mol})$ was 105 added to $\mathrm{H}_{2} \mathrm{O}$ and the $\mathrm{pH}$ of the resulting solution was adjusted to $\mathrm{pH} 9$ by using $1 \mathrm{mM} \mathrm{NaOH} / \mathrm{H}_{2} \mathrm{O}$. The solvent was evaporated to precipitate a dark-red powder of 4 . The powder was collected by filtration, and dried in vacuo \{yield: $72 \%$ based on $\left.[2]\left(\mathrm{NO}_{3}\right)\right\}$. Anal. calc. for \{[D-labeled ${ }_{110} \mathbf{4} \cdot \mathrm{NaNO}_{3}: \mathrm{C}_{21} \mathrm{H}_{40} \mathrm{~N}_{3} \mathrm{NaNiO}_{4} \mathrm{RuS}_{2}: \mathrm{C}, 39.08 ; \mathrm{H}, 6.25 ; \mathrm{N}, 6.51 \%$. Found: C, 39.54; H, 6.68; N, 6.59\%. The sample for the elemental analysis was prepared by method B. $\mathrm{Na}^{+}$and $\mathrm{NO}_{3}{ }^{-}$ 
in the sample could be derived from the $\mathrm{NaOH} / \mathrm{H}_{2} \mathrm{O}$ solution used for adjusting the $\mathrm{pH}$ of the solution and the counteranion of [2] $\left(\mathrm{NO}_{3}\right)$, respectively. The existence of $\mathrm{NO}_{3}^{-}$was confirmed by IR measurement, i.e., a characteristic absorption 5 of uncoordinating $\mathrm{NO}_{3}{ }^{-}$was observed at $1384 \mathrm{~cm}^{-1}$. ESI-MS (in $\mathrm{CH}_{3} \mathrm{CN}$ ) $\mathrm{m} / \mathrm{z} 543.2([4-\mathrm{OH}]+; \mathrm{I}=100 \%$ in the range $\mathrm{m} / \mathrm{z}$ 100-2000). FTIR $\left\{\mathrm{cm}^{-1}\right.$, as a $\mathrm{KBr}$ disk $\}$ : $3433(\mathrm{O}-\mathrm{H}), 1743$ (Ni-H-Ru), 1570 (aromatic $\mathrm{C}=\mathrm{C}$ ), 1473 (aromatic $\mathrm{C}=\mathrm{C}$ ), 1465 (aromatic C=C), 1384 (NO3-), 1328, 1290, 1262, 1207, 1110, 10 1097, 1067, 1044, 1025, 972, 951, 803. XPS: 853.9 eV (Ni $2 \mathrm{p}_{3 / 2}$ region), $280.5 \mathrm{eV}$ ( $\mathrm{Ru} 3 \mathrm{~d}_{5 / 2}$ region).

Typical procedure for hydrogen isotope exchange reaction between gaseous isotopes and medium isotopes catalysed by [2] $\left(\mathrm{NO}_{3}\right)$

${ }_{15}$ A $3 \mathrm{~mL}$ vial was charged with $1.0 \mu \mathrm{mol}$ of [2] $\left(\mathrm{NO}_{3}\right)$ and a stir bar under $\mathrm{H}_{2}$, and was capped with a septum. After injecting 1 $\mathrm{mL}$ of Ar-bubbled $\mathrm{D}_{2} \mathrm{O}$ into the vial, $1 \mathrm{~mL}$ of $\mathrm{H}_{2}$ gas was removed immediately. The vial was stirred (5000 rpm, Nissin magnetic stirrer Model SW-R700) vigorously at $60^{\circ} \mathrm{C}$ for $1 \mathrm{~h}$.

20 The gas present in the vial was sampled using a gas-tight syringe and analysed for $\mathrm{H}_{2}, \mathrm{HD}$ and $\mathrm{D}_{2}$ gases by GC. Isotope ratios for each of the identical runs were averaged. It was confirmed that no isotope exchange reactions between gaseous isotopes and medium isotopes occurred in the absence 25 of $\mathbf{1}, \mathbf{2}$ or $\mathbf{3}$ (as blank experiments). When the experiments were performed using $\mathrm{D}_{2}$ and $\mathrm{H}_{2} \mathrm{O}$, the results were the same except for the isotope effects, and the $\mathrm{H}_{2} / \mathrm{HD}$ ratio was comparable to the $\mathrm{D}_{2} / \mathrm{HD}$ ratio of the $\mathrm{H}_{2} / \mathrm{D}^{+}$isotope exchange reaction.

\section{${ }_{30}$ Typical procedure for the hydrogenation of carbonyl compounds catalysed by 4}

Benzaldehyde (250 mmol) and 4 (3.1 mg, $5.0 \mu \mathrm{mol})$ were dissolved in $\mathrm{H}_{2} \mathrm{O}(2 \mathrm{~mL})$ at $\mathrm{pH} 7-10$. The solution was stirred under $\mathrm{H}_{2}$ at a pressure of $0.1-0.7 \mathrm{MPa}$ at $60^{\circ} \mathrm{C}$. After $1 \mathrm{~h}$, the 35 solution was cooled to $0{ }^{\circ} \mathrm{C}$, and the resulting mixture was extracted by $\mathrm{CDCl}_{3}$. The yield of benzyl alcohol in the $\mathrm{CDCl}_{3}$ solution was determined by ${ }^{1} \mathrm{H}$ NMR with 1,4 -dioxane as an internal standard. It was confirmed that no hydrogenation occurred in the absence of $\mathbf{1}$ or $\mathbf{4}$ (as blank experiments).

\section{${ }_{40}$ Results and discussion}

\section{Behavior of $\mathrm{Ni}(\mu-\mathrm{H}) \mathrm{Ru}$ complexes in acidic media (at pH 4-6)}

Only crystals of $2\{\mathrm{Ni}(\mu-\mathrm{H}) \mathrm{Ru}\}$ and the D-labeled $2\{\mathrm{Ni}(\mu-$ $\mathrm{D}) \mathrm{Ru}\}$ available for $\mathrm{X}$-ray analysis were used for all experiments in this study. It is very important to note that the 45 hydride complex 2 does not react with $\mathrm{H}^{+}$to evolve $\mathrm{H}_{2}$ in acidic media at $\mathrm{pH} 4-6,{ }^{58}$ i.e., complex 2 does not decompose to the aqua complex 1 with the evolution of $\mathrm{H}_{2}$ in acidic media at $\mathrm{pH}$ 4-6. It was confirmed by ESI-MS (Fig. S1 in ESI $\dagger$ ) and IR (Fig. S2 in ESI $\dagger$ ) that the structure of 2 was 50 preserved in acidic media at $\mathrm{pH} 4-6$. The hydrido ligand of 2 exhibits a protic character and undergoes an $\mathrm{H}^{+} / \mathrm{D}^{+}$exchange with $\mathrm{D}^{+}$in $\mathrm{D}_{2} \mathrm{O}$ at $\mathrm{pD} 4-6$ (eqn (4)).

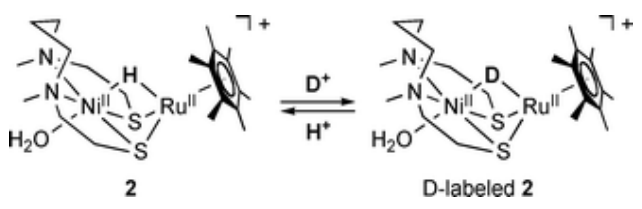

${ }_{55}$ Fig. 4 shows the result of $\mathrm{pD}$-dependent $\mathrm{H}^{+} / \mathrm{D}^{+}$exchange for $15 \mathrm{~min}$ at $60{ }^{\circ} \mathrm{C}$ determined by ESI-MS, which indicates a maximum around $\mathrm{pD} 4$. At $\mathrm{pD} 4-6$, the lower $\mathrm{pD}$ of the solution, the faster is the rate of the $\mathrm{H}^{+} / \mathrm{D}^{+}$exchange, i.e., the rate of the $\mathrm{H}^{+} / \mathrm{D}^{+}$exchange is dependent on $\mathrm{D}^{+}$concentration.

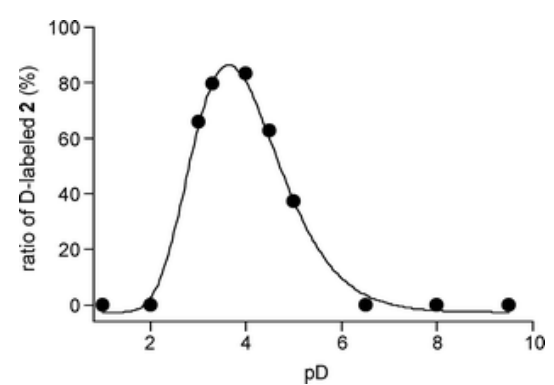

Fig. 4 pD-Dependent $\mathrm{H}^{+} / \mathrm{D}^{+}$exchange of the hydrido ligand of [2] $\left(\mathrm{NO}_{3}\right)$ $(1.0 \mu \mathrm{mol})$ in $\mathrm{D}_{2} \mathrm{O}(1 \mathrm{~mL})$ at $\mathrm{pD} 1-10$ at $60^{\circ} \mathrm{C}$ for $15 \mathrm{~min}$.

\section{A low-valent complex $\mathrm{Ni}^{\mathrm{I}}(\mu-\mathrm{SR})_{2} \mathrm{Ru}^{\mathrm{I}}$}

Complex [2] $\left(\mathrm{NO}_{3}\right)$ was dissolved in $\mathrm{H}_{2} \mathrm{O}$ at $\mathrm{pH} 4-6 . \mathrm{H}_{2}$ gas 65 was bubbled through the solution at $23{ }^{\circ} \mathrm{C}$, to evaporate the solvent, for $1 \mathrm{~h}$. The remaining red oil was extracted with chloroform and the resulting solution was filtered and evaporated under vacuum to yield a dark red powder of $\mathbf{3}$. It is important to note that the low-valent complex $\mathbf{3}$ was not 70 obtained from the reaction of $\mathbf{2}$ with $\mathrm{H}_{2}$ in neutral-basic media at $\mathrm{pH}$ 7-10. Fig. 5a shows a MALDI-TOF mass spectrum of a signal at $m / z 542.1$ relative intensity $(I)=100 \%$ in the range of $\mathrm{m} / \mathrm{z}$ 200-1000\}. The envelope at $\mathrm{m} / \mathrm{z} 542.1$ has a characteristic distribution of isotopomers that matches well 75 with the calculated isotopic distribution for [3] $]^{\circ+}$ (Fig. 5b and 5c). X-Ray photoelectron spectra (XPS) of 3 show that the binding energies of $\mathrm{Ni} 2 \mathrm{p}_{3 / 2}$ and $\mathrm{Ru} 3 \mathrm{~d}_{5 / 2}$ are $852.7 \mathrm{eV}$ and $279.4 \mathrm{eV}$, which correspond to $\mathrm{Ni}(\mathrm{I})$ and $\mathrm{Ru}(\mathrm{I})$, respectively (Fig. 6).$\underline{59}$ The values of the binding energies of $\mathrm{Ni} 2 \mathrm{p}_{3 / 2}$ and ${ }_{80} \mathrm{Ru} 3 \mathrm{~d}_{5 / 2}$ in 3 are lower than those of $[\mathbf{1}]\left(\mathrm{NO}_{3}\right)_{2}\left(\mathrm{Ni} 2 \mathrm{p}_{3 / 2}\right.$ : $853.9 \mathrm{eV}, \mathrm{Ru} 3 \mathrm{~d}_{5 / 2}$ : $\left.280.3 \mathrm{eV}\right) .{ }^{1} \mathrm{H}$ NMR measurement indicates diamagnetism in 3, i.e., the signals of the protons of $\eta^{6}-\mathrm{C}_{6} \mathrm{Me}_{6}$ and $(\mu-\mathrm{SR})_{2}$ of 3 were observed at 2.12 and 1.80 $3.08 \mathrm{ppm}$, respectively. The reason for diamagnetism should 85 be explained on the basis of electronic coupling between the two metal ions $\left(\mathrm{Ni}^{\mathrm{I}}\right.$ and $\left.\mathrm{Ru}^{\mathrm{I}}\right)$. 

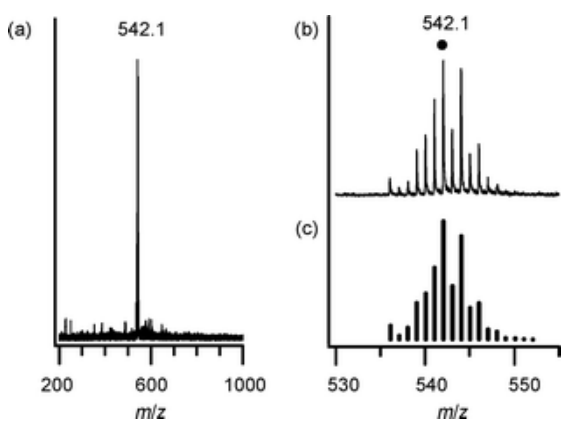

Fig. 5 (a) MALDI-TOF mass spectrum of 3. Dithranol was used as a matrix. The signal at $m / z 542.1$ corresponds to $[3]^{++}$. (b) The signal at $\mathrm{m} / \mathrm{z}$ 542.1. (c) Calculated isotopic distribution for $[3]^{+}$.
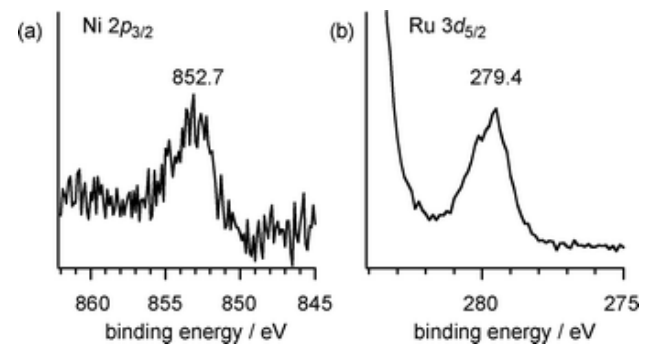

Fig. 6 (a) XPS of Ni 2p region for 3. (b) XPS of Ru 3d region for 3.

Hydrogen isotope exchange reaction between gaseous isotopes and medium isotopes catalysed by the D-labeled 2 in acidic media (at pH 4-6)

10 The D-labeled 2 catalyses a pD-dependent hydrogen isotope exchange reaction between $\mathrm{H}_{2}$ and $\mathrm{D}_{2} \mathrm{O}$ as shown in Fig. 7 . The pD-dependence of the hydrogen isotope exchange reaction between gaseous isotopes and medium isotopes (Fig. 7) is similar to the pD-dependence in the $\mathrm{H}^{+} / \mathrm{D}^{+}$exchange (Fig. $154)$. The evolution of HD and $\mathrm{D}_{2}$ was determined by GC.

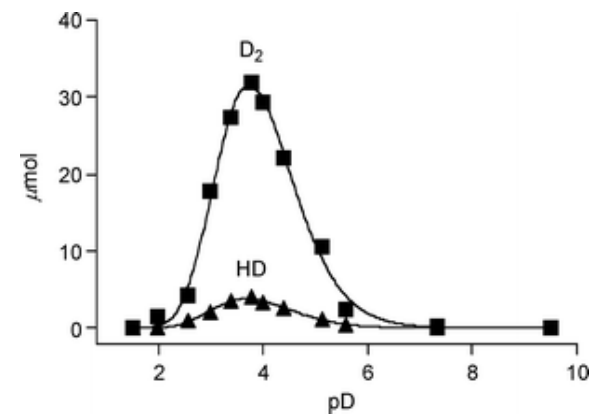

Fig. 7 pD-Dependent generation of $\mathrm{HD}$ and $\mathrm{D}_{2}$ in the reaction of [2] $\left(\mathrm{NO}_{3}\right)$ $(1.0 \mu \mathrm{mol})$ with $\mathrm{H}_{2}\left(2.0 \mathrm{~cm}^{3}, 84 \mu \mathrm{mol}, 0.1 \mathrm{MPa}\right)$ in $\mathrm{D}_{2} \mathrm{O}(1 \mathrm{~mL})$ at $60{ }^{\circ} \mathrm{C}$ for $1 \mathrm{~h}$.

20

The time course of the hydrogen isotope exchange reaction between $\mathrm{H}_{2}$ and $\mathrm{D}_{2} \mathrm{O}$ (or between $\mathrm{D}_{2}$ and $\mathrm{H}_{2} \mathrm{O}$ ) catalysed by the D-labeled 2 (or 2 ) shows that $\mathrm{HD}$ and $\mathrm{D}_{2}$ (or $\mathrm{HD}$ and $\mathrm{H}_{2}$ ) are formed simultaneously as shown in Fig. 8a (or Fig. 8b), 25 which agrees with the time-dependent profile in the hydrogen isotope exchange reaction between gaseous isotopes and medium isotopes by $\mathrm{H}_{2}$ ases. ${ }^{18-30}$ The data of the consumption of $\mathrm{H}_{2}$ (Fig. 8a) and $\mathrm{D}_{2}$ (Fig. 8b) were used for the first-order kinetic plots in Fig. 8c. The consumption of $\mathrm{H}_{2}$ ( or $\mathrm{D}_{2}$ ) obeyed 30 the first-order kinetics over 3-5 half-lives. In this case, a kinetic isotope effect $\left\{\mathrm{KIE}=1.7, k_{\mathrm{obs}}(\mathrm{H})=1.03 \times 10^{-4} \mathrm{~s}^{-1}\right.$ and $\left.k_{\text {obs }}(\mathrm{D})=6.11 \times 10^{-5} \mathrm{~s}^{-1}\right\}$ was observed (Fig. 8c). The presence of the KIE is consistent with a mechanism in which the rate-determining step involves $\mathrm{H}-\mathrm{H}$ (or $\mathrm{D}-\mathrm{D}$ ) bond 35 cleavage.
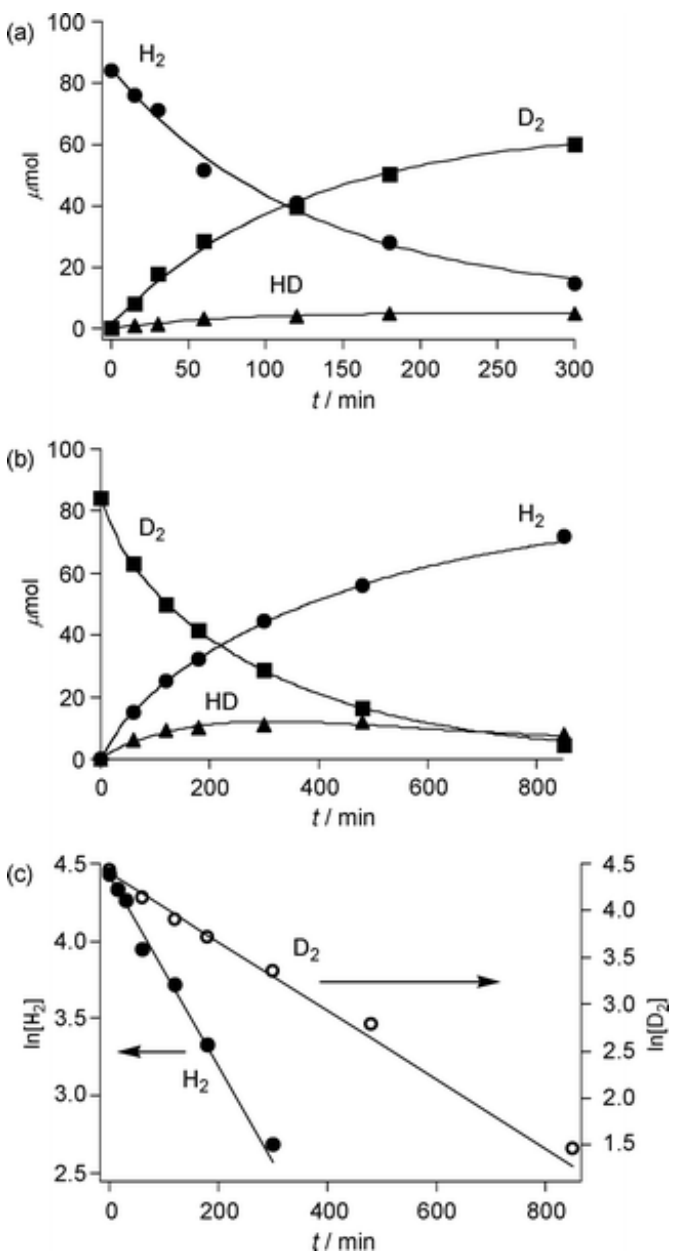

Fig. 8 (a) Time course of the generation of $\mathrm{HD}$ and $\mathrm{D}_{2}$ and the consumption of $\mathrm{H}_{2}$ determined by GC analysis in the reaction of [Dlabeled 2] $\left(\mathrm{NO}_{3}\right)(1.0 \mu \mathrm{mol})$ with $\mathrm{H}_{2}\left(2.0 \mathrm{~cm}^{3}, 84 \mu \mathrm{mol}, 0.1 \mathrm{MPa}\right)$ in $\mathrm{D}_{2} \mathrm{O}$ $40(1 \mathrm{~mL}, \mathrm{pD} 4.0)$ at $60^{\circ} \mathrm{C}$. (b) Time course of the generation of $\mathrm{HD}$ and $\mathrm{H}_{2}$ and the consumption of $\mathrm{D}_{2}$ determined by GC analysis in the reaction of [2] $\left(\mathrm{NO}_{3}\right)(1.0 \mu \mathrm{mol})$ with $\mathrm{D}_{2}\left(2.0 \mathrm{~cm}^{3}, 84 \mu \mathrm{mol}, 0.1 \mathrm{MPa}\right)$ in $\mathrm{H}_{2} \mathrm{O}(1 \mathrm{~mL}$, $\mathrm{pH} 4.0$ ) at $60{ }^{\circ} \mathrm{C}$. (c) The first-order kinetic plots for the consumption of $\mathrm{H}_{2}$ (Fig. 8a) and $\mathrm{D}_{2}$ (Fig. 8b).

45 The pH-dependence and time course of the hydrogen isotope exchange reaction between gaseous isotopes and medium isotopes catalysed by $\mathbf{1}$ and $\mathbf{2}$ are similar to those catalysed by the D-labeled 2 .

Mechanism of the hydrogen isotope exchange reaction 50 between gaseous isotopes and medium isotopes in acidic media

Based on the results obtained, we propose a mechanism of the hydrogen isotope exchange reaction between gaseous isotopes and medium isotopes. In Fig. 9, D-labeled $\mathbf{2}$ is used as a 
starting complex whose $\mu$-D ligand has a $\mathrm{D}^{+}$character, but not a $\mathrm{D}^{-}$character at $\mathrm{pD}$ 4-6 (vide supra). First, the reaction of the D-labeled 2 with $\mathrm{H}_{2}$ may produce a single D-labeled dihydride species $\mathbf{Q}$ (HD hydride) via heterolytic activation of ${ }_{5} \mathrm{H}_{2}$. This may be a rate-determining step for the hydrogen isotope exchange reaction between gaseous isotopes and medium isotopes judging from the observed KIE as shown in Fig. 8c. The $\mathrm{H}^{+} / \mathrm{D}^{+}$exchange of $\mathbf{Q}$ with $\mathrm{D}^{+}$in $\mathrm{D}_{2} \mathrm{O}$ occurs quickly to give a double D-labeled dihydride species $\mathbf{R}$ (DD

10 hydride). Then, intramolecular reductive elimination of HD from $\mathbf{Q}$ and $\mathrm{D}_{2}$ from $\mathbf{R}$ occurs to give the low-valent complex 3. This is the reason why $\mathrm{HD}$ and $\mathrm{D}_{2}$ are produced simultaneously (but not sequentially). To complete the catalytic cycle, the D-labeled $\mathbf{2}$ is regenerated by deuteration

15 of 3. This is totally different from the previously proposed mechanism of the hydrogen isotope exchange reactions between gaseous isotopes $\left(\mathrm{H}_{2}\right)$ and medium isotopes $\left(\mathrm{D}_{2} \mathrm{O}\right)$, where the hydrido ligand of the metal hydride species $(\mathrm{M}-\mathrm{H})$ acts as $\mathrm{H}^{-}$and reacts with medium $\mathrm{D}^{+}$to form $\mathrm{HD}$ as the first 20 step in the reaction. ${ }^{43,47,49}$ It was confirmed that the low-valent complex 3 also catalysed the hydrogen isotope exchange reaction between $\mathrm{H}_{2}$ and $\mathrm{D}_{2} \mathrm{O}$ (or between $\mathrm{D}_{2}$ and $\mathrm{H}_{2} \mathrm{O}$ ).

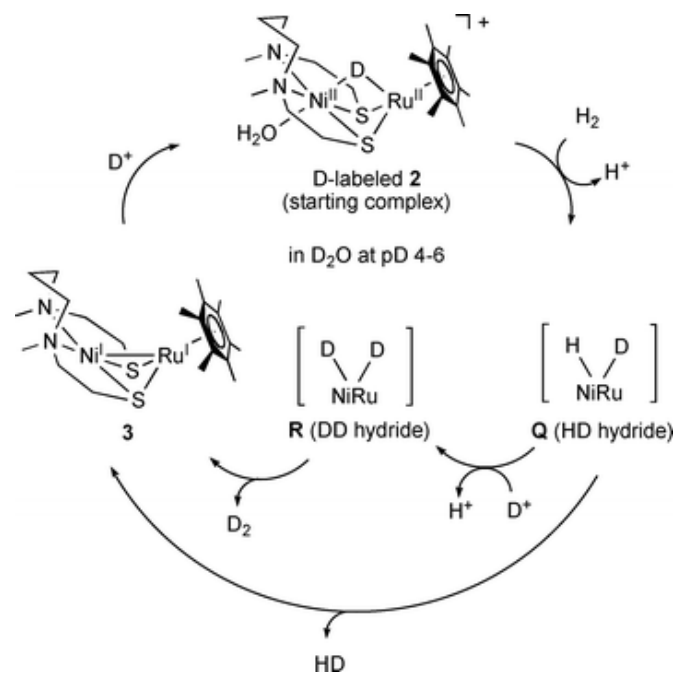

Fig. 9 A proposed mechanism of the hydrogen isotope exchange reaction 25 between gaseous isotopes and medium isotopes. D-Labeled $\mathbf{2}$ is used as a starting complex with $\mathrm{H}_{2}$ in $\mathrm{D}_{2} \mathrm{O}$ at pD 4-6.

Behavior of $\mathrm{Ni}(\mu-\mathrm{H}) \mathrm{Ru}$ complexes in neutral-basic media (at pH 7-10)

${ }_{30}$ Complex $\mathbf{2}$ is reversibly deprotonated to form $\mathbf{4}$, which is a deprotonated species of 2 , in neutral-basic media at $\mathrm{pH} 7-10$ (eqn (5))..$^{60}$
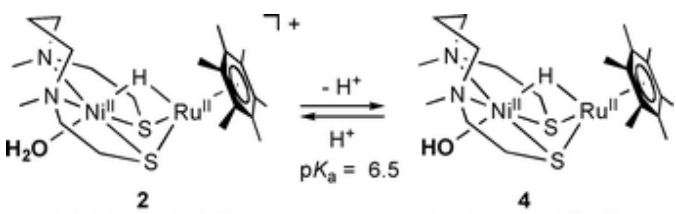

$35 \mathrm{UV}$-vis titration experiments revealed that the $\mathrm{p} K_{\mathrm{a}}$ value of 2 was 6.5 (Fig. 10). It is well known that aqua complexes can deprotonate to form hydroxo complexes in neutral-basic media. ${ }^{61-65}{ }^{1} \mathrm{H}$ NMR measurements indicate paramagnetism in 4 (Fig. S3 in ESI $\dagger$ ). A similar character was observed in $2 .^{53}$

40 In an IR spectrum of $\mathbf{4}$ in the $650-4000 \mathrm{~cm}^{-1}$ region as a $\mathrm{KBr}$ disk, a peak at $3433 \mathrm{~cm}^{-1}$ was assigned to $\mathrm{v}(\mathrm{O}-\mathrm{H})$ that shifts to $2688 \mathrm{~cm}^{-1}$ by isotopic substitution of a hydrogen atom in the hydroxo ligand (OD) ${ }^{66}$ although the $\mathrm{O}-\mathrm{H}$ stretching observed by IR is not direct evidence for the existence of $4 .{ }^{67}$

45

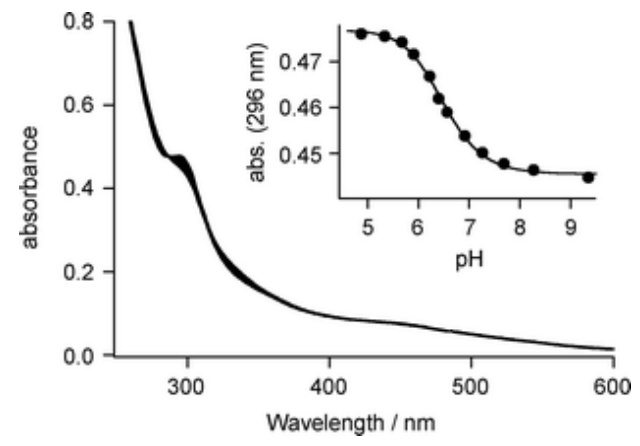

Fig. $10 \mathrm{pH}$-Dependent UV-vis spectra of $2\left(4.7 \times 10^{-5} \mathrm{M}\right)$ in the $\mathrm{pH}$ range 4.5-9.5. The inset gives a plot of absorbance $(l=296 \mathrm{~nm})$ versus $\mathrm{pH}$. Experiments were performed by the titration of 2 with $0.1 \mathrm{M} \mathrm{NaOH} / \mathrm{H}_{2} \mathrm{O}$ at $23{ }^{\circ} \mathrm{C}$.

\section{${ }_{50}$ Stoichiometric hydrogenation of carbonyl compounds with 4} in neutral-basic media at pH 7-10 (without $\mathrm{H}_{2}$ )

Complex $\mathbf{4}$ has a reducing ability toward carbonyl compounds such as benzaldehyde at $\mathrm{pH} \quad 7-10$ under stoichiometric conditions ( 4 : carbonyl compound $=1: 1$ ) in the absence of ${ }_{55} \mathrm{H}_{2}$ (eqn (6)), e.g., benzaldehyde is reduced to benzyl alcohol (yield: 6\%) with 4 at $\mathrm{pH} 8$ at $60{ }^{\circ} \mathrm{C}$ for $1 \mathrm{~h}$.

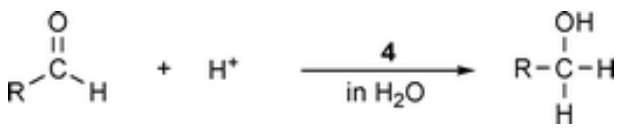

Fig. 11 shows the pH-dependent yield (based on 4) of the $60 \mathrm{O}$-fluorobenzyl alcohol that was obtained by a reaction of $\mathbf{4}$ with $O$-fluorobenzaldehyde under $\mathrm{N}_{2}$ in the absence of $\mathrm{H}_{2}$ at $60{ }^{\circ} \mathrm{C}$ for $15 \mathrm{~min}$, i.e., the reduction takes place in the neutralbasic media at $\mathrm{pH} 7-10$.

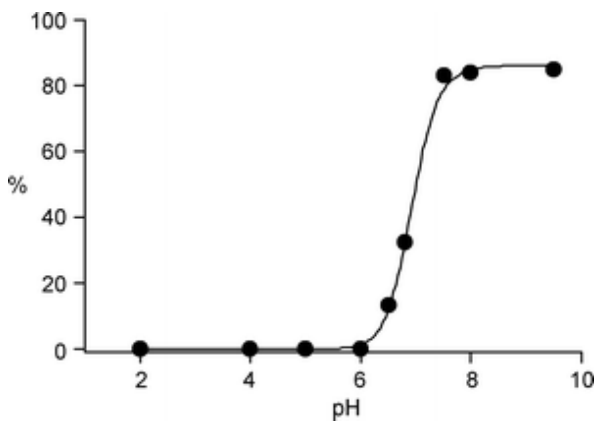

65 Fig. 11 pH-Dependent yield (based on 4) of $o$-fluorobenzyl alcohol from the reaction of $o$-fluorobenzaldehyde ( $500 \mu \mathrm{mol})$ with $4(5 \mu \mathrm{mol})$ in $\mathrm{H}_{2} \mathrm{O}$ $(2 \mathrm{~mL})$ at $60^{\circ} \mathrm{C}$ for $15 \mathrm{~min}$ under $\mathrm{N}_{2}$ in the absence of $\mathrm{H}_{2}$. 
Catalytic hydrogenation of carbonyl compounds with 4 in neutral-basic media at pH 7-10 (with $\mathrm{H}_{2}$ )

On the other hand, under catalytic conditions (0.5 $\mathrm{MPa}$ of $\mathrm{H}_{2}$ ), benzaldehyde (50 equivalents) is reduced to benzyl alcohol 5 catalysed by 4 in $\mathrm{H}_{2} \mathrm{O}$ at $\mathrm{pH} 8$ at $60{ }^{\circ} \mathrm{C}$ for $12 \mathrm{~h}$ (yield: $98 \%$, eqn (7)).

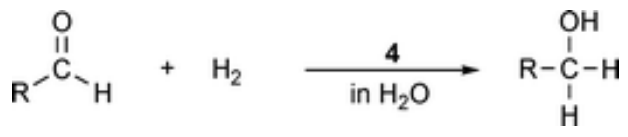

To the best of our knowledge, this is the first example of the 10 hydrogenation of substrates catalysed by $\mathrm{M}(\mu-\mathrm{Z})_{2} \mathrm{M}(\mathrm{M}=$ metal ions, $\mathrm{Z}$ = thiolato, sulfido or hydrosulfido ligands) complexes in aqueous media. ${ }^{54} \mathrm{H}$ NMR experiments revealed that the D-labeled hydrogen atoms were incorporated into the carbonyl compounds when $\mathrm{D}_{2}$ was used as the hydrogen donor 15 in the hydrogenation (eqn (8)).

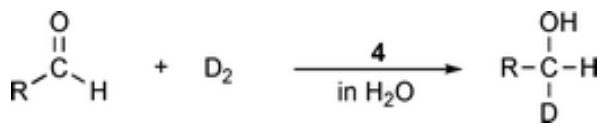

The $\mathrm{pH}$-dependence on the catalytic reduction of glyoxylic acid under $\mathrm{H}_{2}(0.5 \mathrm{MPa})$ is similar to the $\mathrm{pH}$-dependence on 20 the reduction under the stoichiometric conditions described above (Fig. S4 in ESI $\dagger$ ).

Fig. 12 reveals temperature-dependent turnover frequencies $\{$ TOFs $=(\mathrm{mol}$ of product formed $/ \mathrm{mol}$ of catalyst $)$ per $\mathrm{h}\}$ in the hydrogenation of $o$-fluorobenzaldehyde catalysed by 4 in $\mathrm{H}_{2} \mathrm{O}$ 25 at $\mathrm{pH} 8$ at $0.5 \mathrm{MPa}$ of $\mathrm{H}_{2}$. The TOFs of the hydrogenation were drastically increased above $40{ }^{\circ} \mathrm{C}$. The catalytic reactions were carried out at $60{ }^{\circ} \mathrm{C}$, and it was confirmed by ESI-MS that complex 4 was quite stable at $60{ }^{\circ} \mathrm{C}$ under Ar at pH 7-10 in the absence of reducible aldehydes. Fig. 13 shows so the dependence of TOFs upon concentrations of $O$ fluorobenzaldehyde used in the hydrogenation catalysed by 4 in $\mathrm{H}_{2} \mathrm{O}$ at $\mathrm{pH} 8$ at $60{ }^{\circ} \mathrm{C}$. The TOFs of the hydrogenation of aldehydes examined in this study saturate at a $1: 50$ ratio of 4 : aldehydes. As shown in Fig. 14, the TOFs of the 35 hydrogenation of $o$-fluorobenzaldehyde catalysed by 4 in $\mathrm{H}_{2} \mathrm{O}$ at $\mathrm{pH} 8$ at $60{ }^{\circ} \mathrm{C}$ are dependent on the pressure of $\mathrm{H}_{2}$ in the range from 0.1 to $0.5 \mathrm{MPa}$, and saturate at $0.5 \mathrm{MPa}$. Fig. 15 shows the time course of the turnover numbers (= TONs, mol of product formed $/ \mathrm{mol}$ of catalyst) in the hydrogenation of $o$ 40 fluorobenzaldehyde under the optimised catalytic conditions (pH 8, $60^{\circ} \mathrm{C}, 0.5 \mathrm{MPa}$ of $\mathrm{H}_{2}, 1: 50$ ratio of 4 : aldehydes). In addition, it was confirmed that the catalyst 4 could be reused at least three times; i.e., upon addition of more substrates after the reaction, the catalytic cycle was resumed (Fig. 16), though 45 the catalyst $\mathbf{4}$ was gradually deactivated.

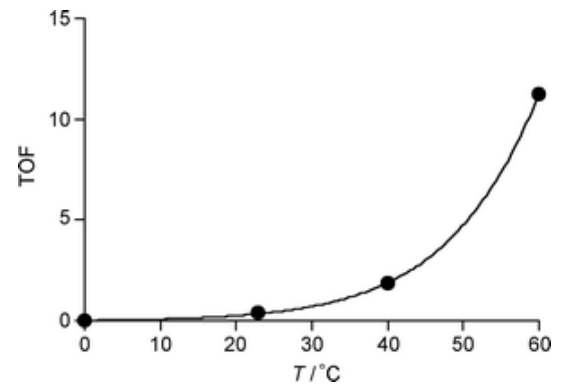

Fig. 12 Temperature-dependent profile of TOFs $\{$ (mol of product formed $/ \mathrm{mol}$ of catalyst) per $\mathrm{h}\}$ of the hydrogenation of $O$ fluorobenzaldehyde $(250 \mu \mathrm{mol})$ with $4(5 \mu \mathrm{mol})$ in $\mathrm{H}_{2} \mathrm{O}(2 \mathrm{~mL})$ at $\mathrm{pH} 8$ at $500.5 \mathrm{MPa}$ of $\mathrm{H}_{2}$.

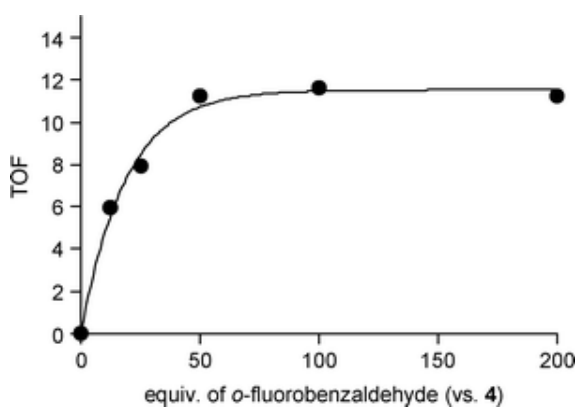

Fig. 13 TOFs $\{$ (mol of product formed/mol of catalyst) per $\mathrm{h}\}$ depending upon the number of moles of substrates for the hydrogenation of 0 fluorobenzaldehyde with $4(5 \mu \mathrm{mol})$ in $\mathrm{H}_{2} \mathrm{O}(2 \mathrm{~mL})$ at $\mathrm{pH} 8$ at $60{ }^{\circ} \mathrm{C}$ at $550.5 \mathrm{MPa}$ of $\mathrm{H}_{2}$.

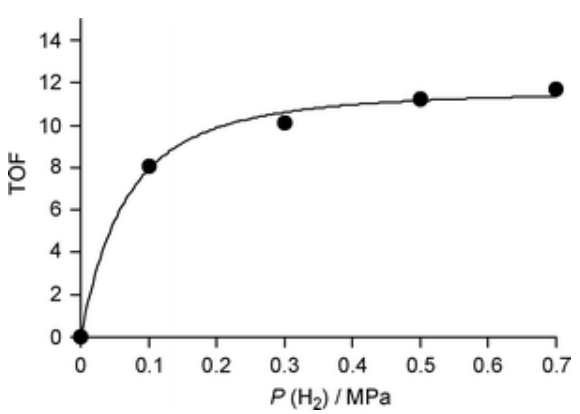

Fig. $14 \mathrm{H}_{2}$ Pressure-dependent TOFs $\{$ (mol of product formed $/ \mathrm{mol}$ of catalyst) per $\mathrm{h}\}$ for the hydrogenation of $o$-fluorobenzaldehyde (250 $\mu \mathrm{mol})$ with $4(5 \mu \mathrm{mol})$ in $\mathrm{H}_{2} \mathrm{O}(2 \mathrm{~mL})$ at $\mathrm{pH} 8$ at $60^{\circ} \mathrm{C}$.

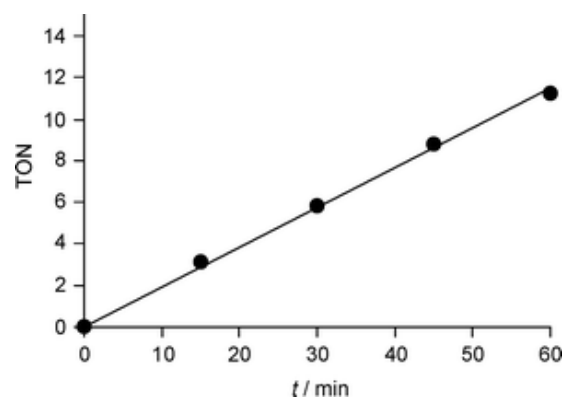

Fig. 15 Time course of the TONs of the hydrogenation of $o$ fluorobenzaldehyde $(250 \mu \mathrm{mol})$ with $4(5 \mu \mathrm{mol})$ in $\mathrm{H}_{2} \mathrm{O}(2 \mathrm{~mL})$ at $60{ }^{\circ} \mathrm{C}$ at $0.5 \mathrm{MPa}$ of $\mathrm{H}_{2}$. 


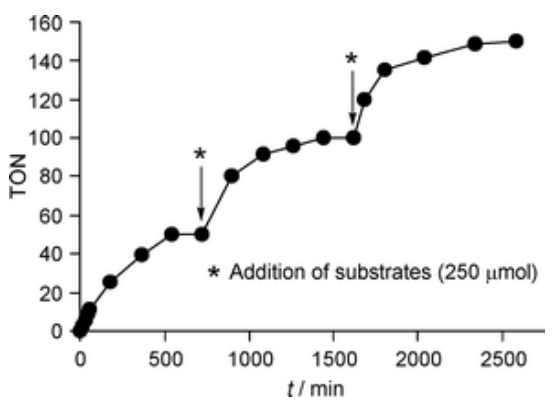

Fig. 16 Resumption of the catalytic hydrogenation of ofluorobenzaldehyde $(250 \mu \mathrm{mol})$ with $4(5 \mu \mathrm{mol})$ in $\mathrm{H}_{2} \mathrm{O}(2 \mathrm{~mL})$ at $60{ }^{\circ} \mathrm{C}$ at $0.5 \mathrm{MPa}$ of $\mathrm{H}_{2}$.

Table 2 summarises the hydrogenation of aldehydes catalysed by $\mathbf{4}$ under the optimised catalytic conditions. The water-soluble aldehyde (glyoxylic acid) is converted to the corresponding alcohol much more efficiently than water10 insoluble aldehydes (benzaldehyde and $o$-fluorobenzaldehyde). The TOF of the hydrogenation of a benzaldehyde derivative containing an electron-withdrawing group (ofluorobenzaldehyde) is higher than the TOF of the hydrogenation of benzaldehyde at $\mathrm{pH} 8$ at $60^{\circ} \mathrm{C}$.

15

Table 2 Hydrogenation of water-soluble aldehydes (entries 1 and 2) in water and water-insoluble aldehydes (entries 3 and 4) in biphasic media catalysed by $\mathbf{4}$ at $\mathrm{pH} 8^{a}$

\begin{tabular}{lllllll}
\hline Entry & Substrate & Product & $\mathrm{TOF}^{b}$ & $t / \mathrm{h}$ & $\mathrm{Yield}(\%)$ & $T /{ }^{\circ} \mathrm{C}$ \\
\hline & 3 & 24 & 44 & 23 \\
\end{tabular}

${ }^{a}$ In the case of biphasic media (entries 3 and 4), the $\mathrm{pH}$ value of the aqueous phase is adopted. ${ }^{b}$ Turnover frequency: (mol of product formed $/ \mathrm{mol}$ of 4) per $\mathrm{h}$

20 Mechanism of the catalytic hydrogenation of carbonyl
compounds

The catalytic cycle of the hydrogenation of the water-soluble and water-insoluble aldehydes catalysed by $\mathbf{4}$ is shown in Fig.

25 17. The hydride complex 4 reacts with aldehydes to afford the corresponding alcohols and the aqua complex $\mathbf{1}$. Complex $\mathbf{4}$ is regenerated by the reaction of the aqua complex $\mathbf{1}$ with $\mathrm{H}_{2}$ at $\mathrm{pH}$ 7-10. It is known that the $\mathrm{H}_{2} \mathrm{O}$ ligand accelerates the heterolytic $\mathrm{H}_{2}$-activation in polar solvents to release $\mathrm{H}_{3} \mathrm{O}^{+}$. ${ }^{68-70}$

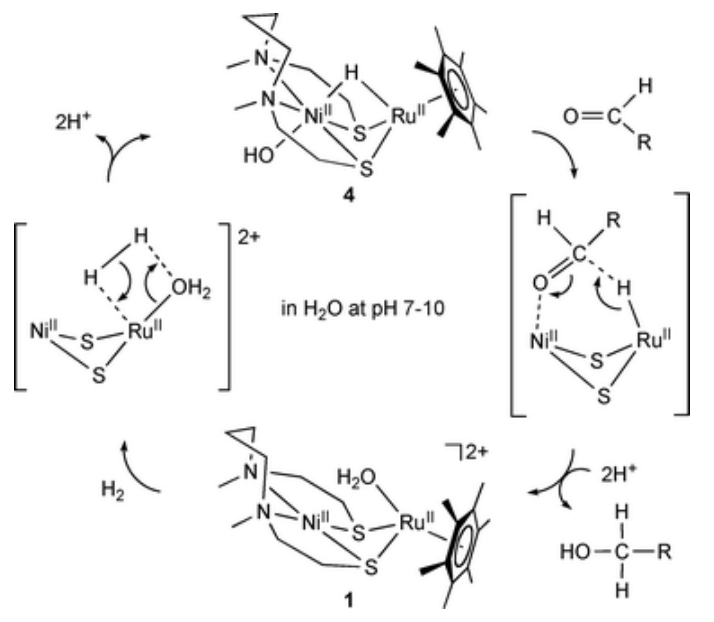

Fig. 17 A proposed mechanism of the hydrogenation of the carbonyl compounds in $\mathrm{H}_{2} \mathrm{O}$ at pH 7-10.

\section{Conclusions}

We have succeeded in the $\mathrm{pH}$-dependent hydrogen isotope 35 exchange reaction between gaseous isotopes and medium isotopes catalysed by 2 at $\mathrm{pH} 4-6$ and hydrogenation of carbonyl compounds catalysed by 4 at $\mathrm{pH} 7-10$. In the hydrogen isotope exchange reaction between gaseous isotopes and medium isotopes, the generation of $\mathrm{HD}$ and $\mathrm{D}_{2}$ (or $\mathrm{HD}$ 40 and $\mathrm{H}_{2}$ ) is simultaneous and $\mathrm{pH}$-dependent, which is similar to $\mathrm{H}_{2}$ ases. A low-valent $\mathrm{Ni}^{\mathrm{I}}(\mu-\mathrm{SR})_{2} \mathrm{Ru}^{\mathrm{I}}$ complex 3 has been isolated by the reaction of 2 with $\mathrm{H}_{2}$ in acidic media at $\mathrm{pH}$ 4-6. The formation of 3 by reductive elimination of $\mathrm{HD}$ and $\mathrm{D}_{2}$ (or $\mathrm{HD}$ and $\mathrm{H}_{2}$ ) from the dihydride species produced by the 45 reaction of 2 with $\mathrm{H}_{2}$ (or $\mathrm{D}_{2}$ ) is the key step for the simultaneous generation of $\mathrm{HD}$ and $\mathrm{D}_{2}$ (or $\mathrm{HD}$ and $\mathrm{H}_{2}$ ). In the hydrogenation, complex $\mathbf{4}$ can reduce the aldehydes to the corresponding alcohols in $\mathrm{H}_{2} \mathrm{O}$. Thus, the $\mu-\mathrm{H}$ ligand of the $\mathrm{Ni}^{\mathrm{II}}(\mu-\mathrm{SR})_{2}(\mu-\mathrm{H}) \mathrm{Ru}^{\mathrm{II}}$ complexes has both protic character (at ${ }_{50} \mathrm{pH} 4-6$ ) and hydridic character (at $\mathrm{pH}$ 7-10) depending on $\mathrm{pH}$.

\section{Acknowledgements}

This work was supported by a grant in aids: 17350027, 17655027, 18033041, and 18065017 (Chemistry of Concerto ${ }_{55}$ Catalysis), and the Global COE Program, "Science for Future Molecular Systems" from the Ministry of Education, Culture, Sports, Science and Technology, Japan.

\section{Notes and references}

601 R. Cammack, M. Frey and R. Robson, Hydrogen as a Fuel: Learning from Nature, Taylor \& Francis, London, 2001.

2 (a) M. Frey, in Structure and Bonding, Springer-Verlag, Berlin, 1998, pp. 97-126; (b) S. P. J. Albracht, Biochim. Biophys. Acta, 1994, 1188, 167-204.

653 N. Tamiya, Y. Yamaguchi, M. Honya and T. Yagi, Biochem. Biophys. Res. Commun., 1966, 22, 43-47.

4 L. E. Mortenson, R. C. Valentine and J. E. Carnahan, J. Biol. Chem., 1963, 238, 1141-1144.

5 J. Pfitzner, H. A. B. Linke and H. G. Schlegel, Arch. Microbiol., 1970, 71, 67-78. 
6 F. S. Jacobson, L. Daniels, J. A. Fox, C. T. Walsh and W. H. OrmeJohnson, J. Biol. Chem., 1982, 257, 3385-3388.

7 C. Zirngibl, W. Van Dongen, B. Schwörer, R. Von Bünau, M. Richter, A. Klein and R. K. Thauer, Eur. J. Biochem., 1992, 208, 511-520.

8 F. Dross, V. Geisler, R. Lenger, F. Theis, T. Krafft, F. Fahrenholz, E. Kojro, A. Duchêne, D. Tripier, K. Juvenal and A. Kröger, Eur. J. Biochem., 1992, 206, 93-102.

9 S. Malki, I. Saimmaime, G. De Luca, M. Rousset, Z. Dermoun and J.-P. Belaich, J. Bacteriol., 1995, 177, 2628-2636.

10 H.-J. Abken, M. Tietze, J. Brodersen, S. Bäumer, U. Beifuss and U. Deppenmeier, J. Bacteriol., 1998, 180, 2027-2032.

11 A. Volbeda, M. H. Charon, C. Piras, E. C. Hatchikian, M. Frey and J. C. Fontecilla-Camps, Nature, 1995, 373, 580-587.

1512 A. Volbeda, E. Garcin, C. Piras, A. L. De Lacy, E. C. Hatchikian, M Frey and J. C. Fontecilla-Camps, J. Am. Chem. Soc., 1996, 118, 12989-12996.

13 Y. Higuchi, T. Yagi and N. Yasuoka, Structure, 1997, 5, 1671-1680.

14 J. W. Peters, W. N. Lanzilotta, B. J. Lemon and L. C. Seefeldt, Science, 1998, 282, 1853-1858.

15 Y. Nicolet, C. Piras, P. Legrand, C. E. Hatchikian and J. C. Fontecilla-Camps, Structure, 1999, 7, 13-23.

16 M. Carepo, D. L. Tierney, C. D. Brondino, T. C. Yang, A. Pamplona, J. Telser, I. Moura, J. J. G. Moura and B. M. Hoffman, J. Am. Chem. Soc., 2002, 124, 281-286.

17 K. A. Vincent, A. Parkin and F. A. Armstrong, Chem. Rev., 2007, 107, 4366-4413 and references therein.

18 D. Rittenberg and A. I. Krasna, Discuss. Faraday Soc., 1955, 20, 185-189.

3019 A. I. Krasna, E. Riklis and D. Rittenberg, J. Biol. Chem., 1960, 235, 2717-2720

20 N. Tamiya and S. T. Miller, J. Biol. Chem., 1963, 238, 2194-2198.

21 T. Yagi, M. Tsuda and H. Inokuchi, J. Biol. Chem., 1973, 73, 10691081.

3522 B. Cavanagh, J. Horiuti and M. Polanyi, Nature, 1934, 133, 797.

23 A. Farkas, L. Farkas and J. Yudkin, Proc. R. Soc. London, Ser. B, 1934, 115, 373-379.

24 Y. Jouanneau, B. C. Kelley, Y. Berlier, P. A. Lespinat and P. M. Vignais, J. Bacteriol., 1980, 143, 628-636.

4025 P. M. Vignais, M.-F. Henry, Y. Berlier and P. A. Lespinat, Biochim. Biophys. Acta, 1982, 681, 519-529.

26 P. Egerer, H. Günther and S. Helmut, Biochim. Biophys. Acta, 1982 703, 149-157.

27 G. D. Fauque, Y. M. Berlier, M. H. Czechowski, B. Dimon, P. A. Lespinat and J. LeGall, J. Ind. Microbiol. Biotechnol., 1987, 2, 15-23.

28 P. M. Vignais, B. Dimon, L. Cournac, N. Zorin, M. Tomiyama and A. Colbeau, J. Bacteriol., 2000, 182, 5997-6004.

29 P. M. Vignais, L. Cournac, E. C. Hatchikian, S. Elsen, L. Serebryakova, N. Zorin and B. Dimon, Int. J. Hydrogen Energy, 2002, 27, 1441-1448.

30 L. Cournac, G. Guedeney, G. Peltier and P. M. Vignais, J. Bacteriol., 2004, 186, 1737-1746.

31 (a) Reviews of hydrogenases model complexes: S. Canaguier, V. Artero and M. Fontecave, Dalton Trans., 2008, 315-325; (b) Specia Issue on Hydrogenases, ed. C. J. Pickett and S. P. Best, Coord. Chem. Rev., 2005, 249, 1517-1690; (c) D. J. Evans and C. J. Pickett, Chem Soc. Rev., 2003, 32, 268-275.

32 X. Zhao, I. P. Georgakaki, M. L. Miller, J. C. Yarbrough and M. Y. Darensbourg, J. Am. Chem. Soc., 2001, 123, 9710-9711.

6033 X. Zhao, I. P. Georgakaki, M. L. Miller, R. Rodrigues-Mejia and M. Y. Darensbourg, J. Am. Chem. Soc., 2002, 41, 3917-3928.

34 M. Y. Darensbourg, E. J. Lyon, X. Zhao and I. P. Georgakaki, Proc. Natl. Acad. Sci. U. S. A., 2003, 100, 3683-3688.

35 I. P. Georgakaki, M. L. Miller and M. Y. Darensbourg, Inorg. Chem., 2003, 42, 2489-2494.

36 M. R. DuBois, M. C. VanDerveer, D. L. DuBois, R. C. Haltiwanger and W. K. Miller, J. Am. Chem. Soc., 1980, 102, 7456-7461.

37 R. T. Weberg, R. C. Haltiwanger, J. C. V. Laurie and M. R. DuBois J. Am. Chem. Soc., 1986, 108, 6242-6250.

7038 C. J. Casewit, D. E. Coons, L. L. Wright, W. K. Miller and M. R. DuBois, Organometallics, 1986, 5, 951-955.
39 L. Carlton, Phosphorus, Sulfur Silicon Relat. Elem., 1987, 59, 231234.

40 H. Kato, H. Seino, Y. Mizobe and M. Hidai, J. Chem. Soc., Dalton Trans., 2002, 1494-1499.

41 A. J. Chalk and J. Halpern, J. Am. Chem. Soc., 1959, 81, 5846-5852.

42 G. A. Mills, S. Weller and A. Wheeler, J. Phys. Chem., 1959, 63, 403-410.

43 J. Halpern and B. R. James, Can. J. Chem., 1966, 44, 671-675.

8044 J. Halpern, B. R. James and A. L. Kemp, J. Am. Chem. Soc., 1966, 88, 5150-5155.

45 J. Halpern, B. R. James and A. L. Kemp, J. Am. Chem. Soc., 1966, 88, 5142-5147.

46 H. E. A. Von Hahn and E. Peters, J. Phys. Chem., 1971, 75, 571-579.

8547 G. Henrici-Olivé and S. Olivé, J. Mol. Catal., 1975/76, 1, 121-135.

48 F. A. Jalón, B. R. Manzano, A. Caballero, M. C. Carrión, L. Santos, G. Espino and M. Moreno, J. Am. Chem. Soc., 2005, 127, 1536415365.

49 P. V. Grundler, O. V. Yazyev, N. Aebischer, L. Helm, G. Laurenczy and A. E. Merbach, Inorg. Chim. Acta, 2006, 359, 1795-1806.

50 Previous studies of time-dependent hydrogen isotope exchange reactions between gaseous isotopes and medium isotopes catalysed by complexes other than the $\mathrm{M}(\mu-\mathrm{Z})_{2} \mathrm{M}$ complexes showed that the generation of $\mathrm{HD}$ and $\mathrm{D}_{2}$ (or $\mathrm{HD}$ and $\mathrm{H}_{2}$ ) is either sequential or simultaneous depending upon catalysts and experimental conditions (see ref. 42-49).

51 (a) M. A. Reynolds, T. B. Rauchfuss and S. R. Wilson, Organometallics, 2003, 22, 1619-1625; (b) Y. Oudart, V. Artero, J. Pécaut and M. Fontecave, Inorg. Chem., 2006, 45, 4334-4336; (c) Y. Oudart, V. Artero, J. Pécaut, C. Leburn and M. Fontecave, Eur. J. Inorg. Chem., 2007, 2613-2626.

52 (a) A. D. Wilson, K. Fraze, B. Twamley, S. M. Miller, D. L. DuBois and M. R. DuBois, J. Am. Chem. Soc., 2008, 130, 1061-1068; (b) A. D. Wilson, R. K. Shoemaker, A. Miedaner, J. T. Muckerman, D. L. 105 DuBois and M. R. DuBois, Proc. Natl. Acad. Sci. U. S. A., 2007, 104, 6951-6956 and references therein.

53 S. Ogo, R. Kabe, K. Uehara, B. Kure, T. Nishimura, S. C. Menon, R. Harada, S. Fukuzumi, Y. Higuchi, T. Ohhara, T. Tamada and R. Kuroki, Science, 2007, 316, 585-587.

11054 (a) T. B. Rauchfuss, Science, 2007, 316, 553-554; (b) C. Mealli and T. B. Rauchfuss, Angew. Chem., Int. Ed., 2007, 46, 8942-8944.

55 J. F. Moulder, W. F. Stiekle, P. E. Sobol and K. D. Bomben, Handbook of X-ray Photoelectron Spectroscopy, Physical Electronics, Inc., Minnesota, 1995.

11556 P. K. Glasoe and F. A. Long, J. Phys. Chem., 1960, 64, 188-190.

57 K. Mikkelsen and S. O. Nielsen, J. Phys. Chem., 1960, 64, 632-637.

58 Below pH 3, complex 2 slowly decomposes to the mononuclear Ru complex $\left[\mathrm{Ru}^{\mathrm{II}}\left(\eta^{6}-\mathrm{C}_{6} \mathrm{Me}_{6}\right)\left(\mathrm{H}_{2} \mathrm{O}\right)_{3}\right]^{2+}$ and uncharacterised products.

59 K. M. Minachev, E. S. Shpiro, O. P. Tkachenko and G. V. Antoshin, Izv. Akad. Nauk. SSSR, Ser. Khim., 1984, 1, 5-26.

60 It is noteworthy that the hydrido ligand of 4 does not undergo $\mathrm{H}^{+} / \mathrm{D}^{+}$ exchange with $\mathrm{D}^{+}$in $\mathrm{D}_{2} \mathrm{O}$ at $\mathrm{pD}$ 7-10.

61 L. Dadci, H. Elias, U. Frey, A. Hörnig, U. Koelle, A. E. Merbach, H. Paulus and J. S. Schneider, Inorg. Chem., 1995, 34, 306-315.

12562 S. Ogo, N. Makihara, Y. Kaneko and Y. Watanabe, Organometallics, 2001, 20, 4903-4910.

63 H. Nakai, S. Ogo and Y. Watanabe, Organometallics, 2002, 21, 1674-1678.

64 S. Ogo, T. Abura and Y. Watanabe, Organometallics, 2002, 21, 2964-2969.

65 T. Abura, S. Ogo, Y. Watanabe and S. Fukuzumi, J. Am. Chem. Soc., 2003, 125, 4149-4154.

66 O. V. Cabal, C. A. Téllez, S. T. Giannerini and J. Felcman, Spectrochim. Acta, Part A, 2005, 61, 337-345.

13567 The exact structure of $\mathbf{4}$ will be determined by X-ray analysis.

68 S. Ogo, H. Nakai and Y. Watanabe, J. Am. Chem. Soc., 2002, 124, 597-601.

69 P. J. Brothers, Prog. Inorg. Chem., 1981, 28, 1-61.

70 B. R. James and M. T. Ashby, Reactions Catalyzed by Inorganic 140 Compounds, in Inorganic Reactions and Methods, ed. A. D. Norman, VCH Publishers, New York, 1991, vol. 16, pp. 71-77. 